\author{
Zbigniew KLEDYŃSKI ${ }^{1}$ \\ Agnieszka MACHOWSKA ${ }^{2}$ \\ Paweł FALACIŃSKI ${ }^{3}$
}

\title{
OCENA JAKOŚCI ROBÓT USZCZELNIAJĄCYCH BUDOWLE OKRESOWO PIĘTRZĄCE WODE NA PRZYKŁADZIE REMONTU ZAPORY W JARNOŁTÓWKU
}

\begin{abstract}
W artykule przedstawiono zakres i przebieg remontu zapory suchego zbiornika przeciwpowodziowego w Jarnołtówku. Zapora - zbudowana w latach 1906-1908 składa się z części kamiennej - przelewowej i zapory ziemnej. Ze względu na stan techniczny zapory kamiennej wykonano ciśnieniową cementację otworową uszczelniającą korpus zapory kamiennej oraz palisadę (metodą jet-grouting) uszczelniającą i wzmacniającą połączenie zapory ziemnej z przyczółkiem zapory kamiennej. Iniekcję otworową wykonano metodą „od dołu”, strefami o wysokości do $5 \mathrm{~m}$, w otworach o orientacji pionowej, w pierwszej i drugiej kolejności iniektowania. Otwory wiertnicze miały średnicę $100 \mathrm{~mm}$ i długość 8,00-24,90 m. Do robót cementacyjnych wykorzystano cement portlandzki CEM I 42,5. Palisadę wykonano ostatecznie z 16 kolumn o średnicy $2,0 \mathrm{~m}$ i wysokości od 15,0 do 18,3 m, zależnej od lokalizacji i głębokości zalegania podłoża skalnego. Do wykonania palisady użyto cementu hutniczego CEM III/A 32,5 N-LH/HSR/NA. Dodatkowo wykonano zakotwienie prawego przyczółka zapory kamiennej. Po wykonaniu remontu dokonano oceny jego skuteczności za pomocą badań geofizycznych obrazujących zmiany prędkości fal sejsmicznych wywołanych cementacją. Otrzymane wyniki porównano $\mathrm{z}$ wynikami badań wykonanych przed remontem zapory w 2009 r. Ze względu na charakter obiektu (okresowo piętrzącego wodę) ocenę wykonano na podstawie wyników kontroli międzyoperacyjnych oraz badań geofizycznych (geosejsmicznych). Podkreślono znaczenie kontroli i nadzorów specjalistycznych w remontach tego typu obiektów.
\end{abstract}

Słowa kluczowe: zapora ziemna, zapora kamienna, suchy zbiornik, cementacja, jet-grouting

\footnotetext{
${ }^{1}$ Zbigniew Kledyński, PW, Wydział Instalacji Budowlanych, Hydrotechniki i Inżynierii Środowiska, ul. Nowowiejska 20, 00-653 Warszawa, 22234 79 28, zbigniew.kledynski@is.pw.edu.pl

2 Autor do korespondencji/corresponding author: Agnieszka Machowska, PW, Wydział Instalacji Budowlanych, Hydrotechniki i Inżynierii Środowiska, ul. Nowowiejska 20, 00-653 Warszawa, 2223453 33, agnieszka.machowska@is.pw.edu.pl

${ }^{3}$ Paweł Falaciński, PW, Wydział Instalacji Budowlanych, Hydrotechniki i Inżynierii Środowiska, ul. Nowowiejska 20, 00-653 Warszawa, 2223453 34, pawel.falacinski@is.pw.edu.pl
} 


\section{Charakterystyka zapory}

Zaporę zbudowano $\mathrm{w}$ celu utworzenia suchego, sterowanego zbiornika przeciwpowodziowego. Budowla piętrzy wodę tylko w okresach krótkotrwałych, zwykle gwałtownych wezbrań formujących się w niewielkiej, górskiej zlewni Złotego Potoku. Całkowita powierzchnia zbiornika, przy maksymalnej rzędnej piętrzenia 378,20 mn.p.m., wynosi $\mathrm{F}=58,8$ ha, a pojemność $\mathrm{V}=2,365 \mathrm{hm}^{3}$. W czaszy zbiornika są łąki i pastwiska [7].

Obiekt piętrzący tworzą: zapora ziemna z ekranem iłowym oraz sekcja przelewowo-upustowa murowana z kamiennych bloków. Długość zapory ziemnej - wykonanej z gruntów miejscowych - wynosi 590 m, jej szerokość w koronie $4 \mathrm{~m}$, a nachylenie skarp: odwodnej 1:4 i odpowietrznej 1:2. Kamienną sekcję przelewowo-upustową zbudowano $\mathrm{z}$ miejscowych łupków grafitowych łączonych zaprawą cementową. Podłoże zbudowane jest z paleozoicznych, zmetamorfizowanych łupków grafitowo-frylitowych [2].

Kamienna sekcja przelewowo-upustowa (fot. 1) - o długości w koronie równej $60 \mathrm{~m}$, maksymalnej wysokości $18,90 \mathrm{~m}$, szerokości podstawy w poziomie dna spustu dennego $10,30 \mathrm{~m}$ - ma następujące otwory upustowe:

- przelew o świetle $40 \mathrm{~m}$ i progu na rzędnej $377,80 \mathrm{~m}$ n.p.m.;

- niezamykany, półkolisty otwór spustu górnego o przekroju $1,3 \mathrm{~m}^{2}$, długości $5,2 \mathrm{~m}$ i zdolności przepustowej $10,3 \mathrm{~m}^{3} / \mathrm{s}$ (przy PP = 377,80 m n.p.m.);

- spust boczny o przekroju kołowym o średnicy 1,2 m, długości 8,7 m i zdolności przepustowej $14,8 \mathrm{~m}^{3} / \mathrm{s}$ (przy PP jak wyżej), zamykany zasuwą płaską o napędzie mechanicznym;

- spust denny o przekroju półkolistym o powierzchni $1,95 \mathrm{~m}^{2}$, szerokości 2,0 m, wysokości $1,2 \mathrm{~m}$ i zdolności przepustowej $28,7 \mathrm{~m}^{3} / \mathrm{s}$ (przy PP jak wyżej), zamykany zasuwą płaską o napędzie mechanicznym.

\section{Historia obiektu i zmiany jego stanu technicznego}

Nie zachowały się żadne dokumenty dotyczące budowy i okresu eksploatacji do końca drugiej wojny światowej, jak również z pierwszych lat powojennych. W latach siedemdziesiątych XX w. stwierdzono podczas wezbrań występowanie przecieków przez spoiny zapory kamiennej. Badania wykazały, że przecieki spowodowane zostały przez ubytki i rozluźnienie zaprawy cementowej. Nieszczelności występowały również w podłożu zapory [1]. Dlatego też w 1986 r. obniżono dopuszczalną rzędną piętrzenia.

W latach 1988-1989 przeprowadzona została cementacja zapory kamiennej i jej podłoża skalnego [2], po której przywrócono dopuszczalną rzędną piętrzenia [4].

W 1999 roku wykonano po raz pierwszy badania geofizyczne (sejsmiczne) kamiennej części zapory [5]. Zgodnie z instrukcją wykonano je po podniesieniu się poziomu górnej wody powyżej stanu alarmowego (2008 r.), a także po zaobserwowaniu niepokojących wypływów wody z korpusu zapory kamiennej 

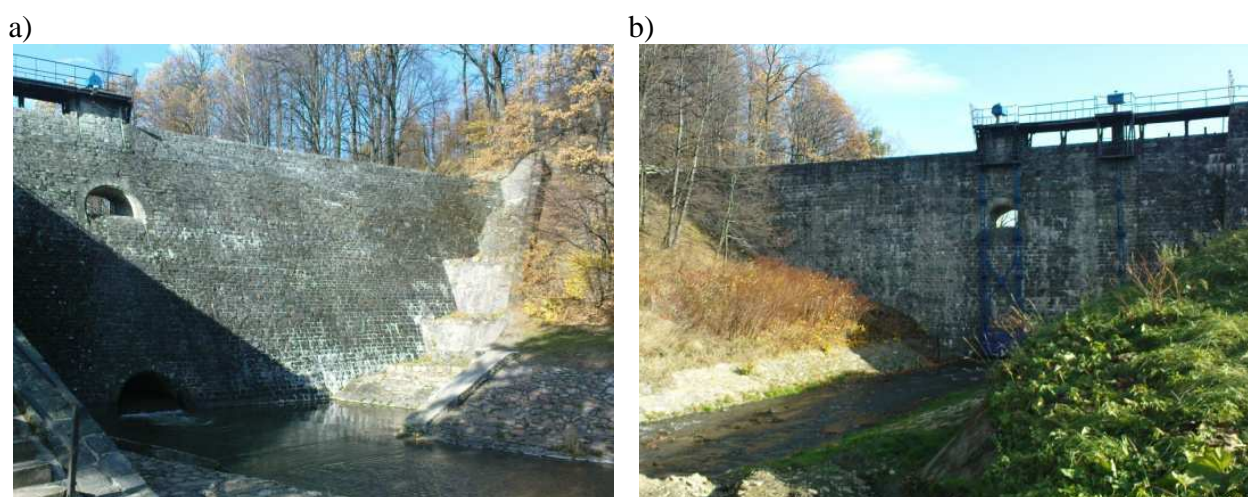

Fot. 1. Zapora kamienna od strony wody dolnej a) i górnej b) - stan w roku 2008

Fot. 1. The stone dam: a) downstream side, b) upstream side - state in 2008

w czerwcu 2009 r. [6]. Wtedy także zauważono pionowe zarysowanie między przemurowanym w roku 2008 skrzydełkiem prawego przyczółka zapory kamiennej (od strony wody górnej) i masywem przyczółka [7].

\section{Zakres remontu}

W efekcie oceny rozpoznanych uszkodzeń, wyników badań i obserwacji podjęto decyzję o remoncie kamiennej części zapory, polegającym na iniekcjach (cementacji) masywu kamiennego i kontaktowej strefy podłoża oraz na oczyszczeniu i uzupełnieniu spoin, naprawie przyczółków progu niecki i betonowych murów oporowych bystrza na lewym przyczółku zapory.

Ponadto zalecono dogęszczenie i doszczelnienie styku kamiennego bloku upustowego z nasypem zapory ziemnej z wykorzystaniem technologii iniekcji strumieniowej wysokociśnieniowej (jet-grouting) [7]. Istotnym uzasadnieniem dla tego zakresu prac była ocena robót uszczelniających wykonanych w latach 1988-89 [3].

\section{Przebieg remontu}

\subsection{Iniekcja styku zapory ziemnej z murem kamiennym}

Prace polegające na oczyszczeniu spoin i ich uzupełnieniu szczelną zaprawą cementową wykonano na wszystkich dostępnych powierzchniach zapory w roku 2010. W tym samym roku powstał projekt [9] iniekcji uszczelniającej korpus kamienny i styk tego korpusu z nasypem zapory ziemnej, będący rozwinięciem koncepcji remontu [7]. Projekt był później dostosowywany do warunków prowadzenia robót, w ramach nadzoru autorskiego [10].

Uszczelnienie styku zapory kamiennej z nasypem zapory ziemnej wykonano $\mathrm{w}$ technologii jet-grouting w celu wytworzenia w styku z murem mieszanki cementogruntu o podwyższonej szczelności i wytrzymałości względem materiału 
nasypu. Oś przesłony wyznaczono ostatecznie (po sondowaniu) w odległości ok. $2 \mathrm{~m}$ od widocznego na korownie obrysu konstrukcji murowej, a odległości między osiami kolumn miały na celu zapewnienie min. 1,0 m szerokości przesłony uszczelniającej (rys. 1).

$\mathrm{W}$ trakcie sondowania nasypu ziemnego ( $\mathrm{z}$ użyciem wody i powietrza) stwierdzono przepływ tych mediów do niecki wypadowej oraz lokalne wysięki wody na powierzchni muru oporowego oddzielającego nasyp zapory od dolnego stanowiska sekcji upustowej. Na palisadę złożyło się ostatecznie 16 kolumn o średnicy $2,0 \mathrm{~m}$ i wysokości od 15,0 do 18,3 m, zależnej od lokalizacji i głębokości zalegania podłoża skalnego. Wykorzystano cement hutniczy CEM III/A 32,5 N-LH/HSR/NA [11].

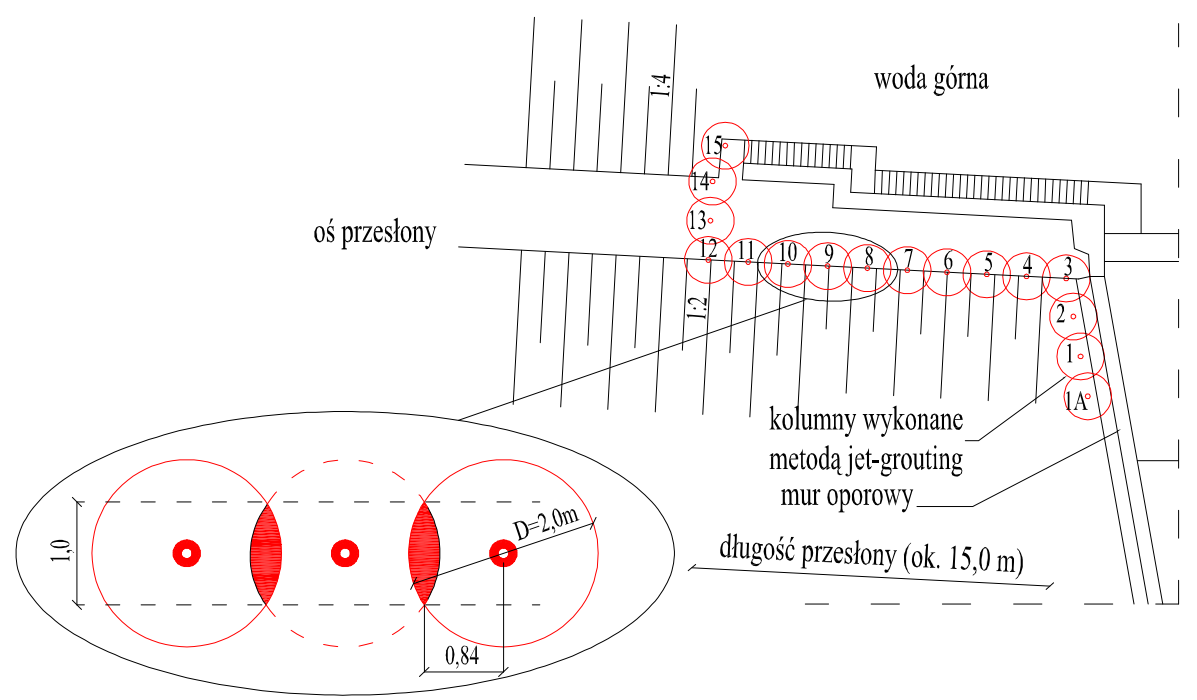

Rys. 1. Przebieg przesłony wykonanej metodą jet-grouting (na podstawie [11])

Fig. 1. Cutoff wall executed with means of jet-grouting method (based on [11])

\subsection{Ciśnieniowa iniekcja otworowa korpusu muru kamiennego zapory}

W ramach kolejnego etapu remontu wykonano ciśnieniową iniekcję otworową (tzw. cementację) muru kamiennego, która miała na celu wypełnienie pustek w spoinach i spękaniach kamieni.

Projekt zakładał iniekcję ciśnieniową korpusu kamiennego poprzez wykonanie pionowych otworów wiertniczych o średnicy ok. $100 \mathrm{~mm}$ i długości 8,00-24,90 mb [9, 10]. Iniekcję wykonano metodą ,od dołu”, strefami o wysokości do $5 \mathrm{~m}$, w otworach pierwszej i drugiej kolejności iniektowania (efektywny rozstaw otworów to $1 \mathrm{~m}$ ). Na szerokości otworów spustowych otwory cementacyjne zostały nawiercone przez ich światło, a strefy iniekcyjne wyodrębniono pakerami. Do robót cementacyjnych wykorzystano cement portlandzki CEM I 42,5. Wskaźnik wodno-cementowy zmieniał się od 4:1 do 1:1, zależnie od zaczyno- 
chłonności i ciśnienia zatłaczania. Otwory cementacyjne po iniekcji wypełniano gęstym zaczynem cementowym o w/c $=0,5$, $\mathrm{z}$ domieszką chemiczną.

Z uwagi na wcześniejszą realizację palisady i obserwację obiektu podczas jej wykonywania, doprojektowane zostały trzy dodatkowe otwory w korpusie kamiennym na prawym skrzydle celem doszczelnienia styku nasypu ziemnego i części kamiennej konstrukcji oraz wypełnienia kawern i możliwych pustek powietrznych po robotach przy palisadzie.

Prace iniekcyjne zostały udokumentowane [12] w formie metryk otworów, w których przedstawiono m.in. długości stref, składy zaczynów, ciśnienia tłoczenia i czasy ich utrzymywania, zaczynochłonności i cementochłonności dla stref, temperatury powietrza i zaczynu, dane o ewentualnych przebiciach itp.

Dodatkowo wykonano zabezpieczenie skrzydełka prawego przyczółka zapory kamiennej poprzez nawiercenie kotew w systemie Gonar.

\section{Ocena prac remontowych}

W zdecydowanej większości przypadków wykonywania prac uszczelniających na obiektach hydrotechnicznych najprostszym i najbardziej miarodajnym sposobem sprawdzenia skuteczności wykonanych zabiegów jest obciążenie obiektu wodą (próba wodna, próbne piętrzenie). W wypadku obiektów piętrzących wodę okresowo (suche zbiorniki, wały przeciwpowodziowe, poldery itp.) zorganizowanie próby szczelności nie jest proste. Taki obiekt, jak przedstawiony zbiornik suchy, z zamknięciami, można by teoretycznie napełnić wodą przez ograniczenie przepływu do nienaruszalnego i gromadzenie wody. Trwałoby to jednak długo, gdyż przepływy w Złotym Potoku są przez większość roku niewielkie, a sam zbiornik napełnia się nimi tylko incydentalnie, w sytuacji ekstremalnych dopływów powodziowych. Próba spiętrzenia wody przeciągnęłaby się więc na tyle, że budowle piętrzące, a zwłaszcza zapora ziemna, pracowałyby w warunkach długotrwałego, wolno zmiennego piętrzenia, czyli w warunkach innych, niż przyjęte do projektowania obiektu. Przeciągająca się z podanych powodów próba mogłaby się okazać nie tylko niemiarodajna dla oceny szczelności , ale nawet niebezpieczna dla stanu technicznego obiektu. W tych okolicznościach ocenę wykonanych robót remontowych (w oczekiwaniu na sprawdzian w czasie nieprzewidywalnego co do wielkości i terminu wystąpienia wezbrania) oparto na ocenie prawidłowości przebiegu prac (nadzór autorski, inwestorski i geologiczny), wynikach badań rdzeni, wodochłonności i cementochłonności przy robotach iniekcyjnych oraz rezultatach badań geofizycznych.

Największe cementochłonności odnotowano w miejscach, w których spodziewano się największych rozluźnień: sąsiedztwo nasypu zapory ziemnej, partie muru pod otworami spustowymi (najprawdopodobniej nie iniektowano ich w latach 1988-89 z powodu trudności technicznych, przezwyciężonych w latach 2011-12) oraz w strefie kontaktowej: mur kamienny-podłoże skalne. Bezwzględne wartości cementochłonności, zwłaszcza gdy je odnieść do zużycia spoiwa w iniektowaniu ośrodków skalnych pod zaporami wodnymi, nie były znaczące. Należy mieć jednak 
na uwadze rodzaj iniektowanego ośrodka (mur z mało porowatych kamieni) i zmierzone wielkości odnosić do zużycia iniektów w pracach uszczelniających konstrukcje murowane i betonowe. Warto także zauważyć, że badania wodochłonności muru i towarzyszące im obserwacje ewentualnych kontaktów hydraulicznych (przecieków) stanowiły rodzaj badania i oceny szczelności całej przegrody kamiennej. Wodochłonności i cementochłonności pozostawały ze sobą dobrze skorelowane.

W latach 1999, 2008 i 2009, w ramach oceny stanu technicznego obiektu, wykonano badania sejsmiczne kamiennego korpusu zapory $[5,6]$. Pomiary wykonano metodą prześwietleń sejsmicznych z tomograficznym odwzorowaniem rozkładu prędkości fal w obrębie muru kamiennego. Po zakończeniu prac remontowych w 2012 r. wykonano badania geofizyczne zapory kamiennej w celu określenia zmian prędkości fal sejsmicznych wywołanych cementacją, aby na tej podstawie ocenić skuteczność prac iniekcyjnych [8].

Otrzymane wyniki porównano z badaniami wykonanymi w 2009 r. (rys. 2). W rezultacie wykonanego spoinowania oraz cementacji korpusu zapory uzyskano na ścianach odpowietrznej i odwodnej wzrost prędkości fal sejsmicznych rzędu $10 \%$. Wskazuje to na znaczący wzrost wytrzymałości i szczelności materiału korpusu zapory kamiennej w iniektowanej strefie.

\section{Wnioski}

Prace remontowe polegające na uszczelnianiu obiektów okresowo piętrzących wodę powinny być prowadzone pod szczególnie wnikliwym nadzorem wykonawcy i inwestora, a także autora projektu oraz - zależnie od rodzaju robót specjalistycznym nadzorem technologicznym (geologiczny, geotechniczny, materiałowy itp.).

Częsta niemożność zaprojektowania miarodajnych prób szczelności, które można by zrealizować w warunkach kontrolowanych i bezpiecznych dla stanu obiektu powinna być kompensowana przez rozszerzony zakres kontroli między operacyjnych i badań, których wyniki przynajmniej pośrednio pozwolą ocenić jakość wykonanych robót.

Zaleca się, aby w badaniach kontrolnych wykorzystywać metody geofizyczne, przy czym ich wyniki będą najbardziej miarodajne, jeśli badania takie zostaną wykonane przed podjęciem robót i po ich zakończeniu. Zarówno badanie wyjściowe, jak i końcowe powinny być zrealizowane według tej samej metodyki i w możliwie zbliżonych warunkach.

\section{Literatura}

[1] PGBW "Hydrogeo": Sprawozdanie z prac badawczych w korpusie i podłożu zapory kamiennej w Jarnołtówku woj. opolskie, Kraków 1984.

[2] PGBW "Hydrogeo": Projekt prac cementacyjnych dla uszczelnienia kamiennego korpusu zapory w Jarnołtówku woj. opolskie, Kraków 1986. 

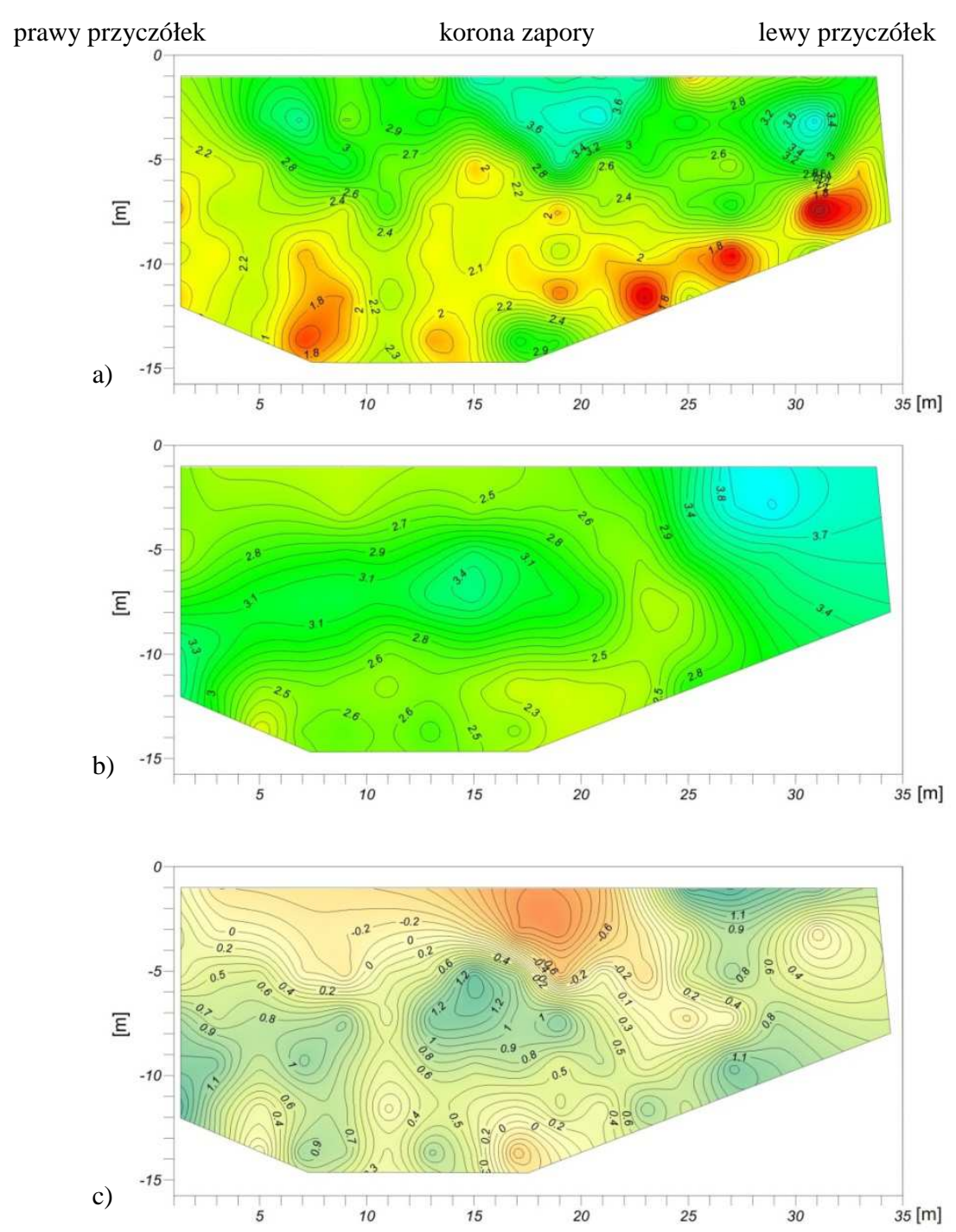

Rys. 2. Prędkości fal sejsmicznych vp [km/s] na powierzchni odwodnej zapory kamiennej (widok od strony wody dolnej); a) rozkład prędkości w 2009 r., b) rozkład prędkości w 2012 r, c) różnice prędkości (mapa b minus mapa a) (na podstawie [8])

Fig. 2. Velocity of seismic waves $\mathrm{Vp}[\mathrm{km} / \mathrm{s}]$ on upstream surface of stone dam (downstream view); a) velocity distribution in 2009 , b) velocity distribution in 2012, c) difference of velocity in 2012 and 2009 (based on [8])

[3] PGBW "Hydrogeo": Dokumentacja z prac cementacyjnych wykonanych celem uszczelnienia korpusu kamiennego i podłoża zapory w rzece Złoty Potok w Jarnołtówku, Kraków 1989. 
[4] Fiedler K. i inni: Analiza stanu pracy zapory Jarnołtówek na Złotym Potoku po wykonanym remoncie przy zastosowaniu metody elementów skończonych, IZwWiBW Politechniki Warszawskiej, Warszawa 1991.

[5] Bestyński Z.: Dokumentacja badań geofizycznych kamiennego przelewu zapory w Jarnołtówku, GEO-Refleks, Warszawa 1999.

[6] Bestyński Z.: Dokumentacja badań geofizycznych kamiennego bloku zapory w Jarnołtówku, GEO-Refleks, Warszawa XI.2008, VIII.2009.

[7] Fiedler K. (1996-2007), Kledyński Z. z zespołem (2008-2015). Doroczne analizy i interpretacja wyników obserwacji i pomiarów zapory suchego zbiornika przeciwpowodziowego w Jarnołtówku na Złotym Potoku, IZwWiBW (od 2008 r. Zakład Budownictwa Wodnego i Hydrauliki) Politechniki Warszawskiej, Warszawa.

[8] Bestyński Z.: Dokumentacja badań geofizycznych kamiennego bloku zapory w Jarnołtówku, GEO-Refleks, Warszawa 2012.

[9] Kledyński Z. z zespołem: Remont kamiennej części zapory suchego zbiornika Jarnołtówek, gm. Głuchołazy, ZBWiH Politechniki Warszawskiej, Warszawa 2010.

[10] Kledyński Z. z zespołem: Zmiana do projektu pt.: Remont kamiennej części zapory suchego zbiornika Jarnołtówek, gm. Głuchołazy, ZBWiH Politechniki Warszawskiej, Warszawa 2011.

[11] Pasternak W.: Dokumentacja powykonawcza pt.: Remont kamiennej części zapory suchego zbiornika Jarnołtówek, Skanska 2012.

[12] Łukaszek R.: Dokumentacja z przebiegu prac cementacyjnych na zaporze kamiennej w Jarnołtówku, gm. Głuchołazy, Geoserwis 2012.

\section{QUALITY ASSESSMENT OF CEMENTING WORKS IN TEMPORARY IMPOUNDING DAMS ON THE EXAMPLE OF JARNOŁTÓWEK STONE DAM}

\section{S u m m a r y}

The article shows the range and technology of repair of dam in temporary impounding reservoir Jarnołtówek. The dam - built in years 1906-1908 - is composed of stone dam - spillway and earth dam. Cementing grouting technology was chosen to seal leaking dam's body. There was also a palisade executed with means of jet-grouting method, which sealed and strengthened the connection between earth dam and abutment of stone dam. Injection was conducted "from the bottom", in zones 5,0 $\mathrm{m}$ high, in vertical holes of first and second order. Dimensions of the holes were: diameter equal $100 \mathrm{~mm}$ and length from 8,0 to $24,9 \mathrm{~m}$. Portland cement of strength class equal 42,5 was used for injection. Palisade finally was made of 16 columns of diameter equal 2,0 m and length - from 15,0 to $18,3 \mathrm{~m}$. To execute the palisade the blast-furnace cement type CEM III/A 32,5 N-LH/HSR/NA was used. Also anchorage of right abutment of stone dam was executed. The quality of repair was controlled with means of geophysics (geoseismic) testing and within working time of the object (temporary impounding water). Obtained results were compared with the results of tests conducted in 2009 (before the dam repair). Significance of control and specialist's supervision in repairs of this type of objects were emphasized in the article.

Keywords: earth dam, stone dam, dry reservoir, cementation, jet-grouting

Przestano do redakcji: 07.06.2016 r.

Przyjęto do druku: $30.06 .2016 r$.

DOI: $10.7862 / r b .2016 .56$ 